\title{
AN ENTREPRENEUR'S GUIDE TO DECIPHERING THE FORMER U.S.S.R. AND EASTERN EUROPEAN MARKETS
}

\author{
Michael G. Harvey \\ University of Oklahoma \\ Norman, OK \\ Kiril Kovatchky \\ Pimex Trading Co., Ltd. \\ Bulgaria
}

\begin{abstract}
When the Berlin Wall came down in 1989, most Western businesspersons recognized the market potential of the Eastern European Bloc of countries and later the former U.S.S.R. Both the consumer and industrial markets were in need, as they are today, of large quantities of updated products and technology. The process of segmenting the demands of consumers in various markets becomes the key to success for entrepreneurial firms. This paper describes a means to develop a dynamic segmentation strategy and entry modes that are most appropriate for each of the market segments of the former U.S.S.R. and Eastern European countries.
\end{abstract}

\section{Introduction}

The fall of the Berlin Wall opened the way for western businesses to reach an untapped market of 400 million consumers (Collins \& Rodrik, 1992). The initial euphoria with such headlines as "Gold Rush: Your Small Business Can Make Millions in the U.S.S.R. and the East Bloc" (Poe, 1990), however, soon gave way to pessimism. Exaltations such as "It's the frontier, or the wild West" (Haslach, 1992) quickly turned into frustration as hopes for rapid expansion and profits did not come to fruition. Lack of information and knowledge about the local people, their culture and postcommunist conditions made businessowners conclude that their efforts would not be successful in the near-term (Wood, 1992; Manakkalathil \& Chelminski, 1993).

Although the region has been called "The Eastern Bloc," it consists of vastly different countries with unique cultural and historical backgrounds. This diversity makes it difficult for Westerners to successfully sell their products there. Perhaps the most important lesson since 1989 has been that rebuilding Eastern Europe's economies and the former U.S.S.R. will be a long-term task that will do nothing to boost western companies' earnings per share in the near future (Wood, 1992). Successful Western companies will have specific market objectives and recognize the differences among the countries. In addition, to have an 
opportunity to succeed, they must also gain insight into the differences among the countries of the Eastern Bloc and the many Republics that now constitute the Commonwealth of Independent States (CIS), formerly the U.S.S.R. Longterm commitment, global perspective, up-to-date information about local market conditions, and the rapidly evolving regulatory environment of those countries will be crucial to succeeding in the Eastern European marketplaces.

This paper examines and compares entry modes available to entrepreneurs interested in international expansion to Eastern European countries and addresses the strengths and weaknesses of alternative strategies related to clusters of countries in the Eastern Bloc. By following a segmentation strategy and not assuming the Eastern Bloc or former U.S.S.R. are homogeneous, entrepreneurial organizations will be able to effectively compete in niches in Eastern European markets. To be truly effective in these markets, small entrepreneurial companies must develop a competitive advantage unique to their companies in the emerging free enterprise countries in which they are conducting business at the time (Bamberger, 1989).

\section{Segmentation/Clustering Eastern European Markets}

\section{Traditional Political Segmentation}

Most of the entrepreneur's knowledge of Eastern Europe and the former U.S.S.R. is based on the history/politics and, to some degree, the cultures of this geopolitical area. Traditionally, most of the political and economic experts in the West have tended to group the Eastern European countries in the following clusters (Congressional, 1990; Quelch, Joachimsthaler \& Nueno, 1991; Collins \& Rodrik, 1991; Wood, 1992): (1) Poland, Hungary, Czech, Slovak (Central Europe); (2) Bulgaria, Romania, Albania (The Balkans); (3) Commonwealth of Independent States (The former U.S.S.R.); (4) Estonia, Lithuania and Latvia (The Baltic Republics) and (5) The former Yugoslavia (consisting of Serbia, Montenegro, Croatia, Slovenia, Bosnia and Herzegovina, and Macedonia).

This market clustering is based primarily on the timing and pace of the economic and political reforms, as well as, on their geographic locations. The countries of the first cluster started economic and political reform earlier and, therefore, have been more visible to the Western experts. These countries experienced major economic declines of about 16 percent in GDP in 1990 (Poland and Hungary) and 1991 (Czechoslovakia). After that, the economies of Poland (1991) declined by only seven percent and five percent for Czechoslovakia (1992) while Hungary's economy was flat in 1992. Many economists are ready to consider these declines in GDP as an indicator for relative recovery in these countries. (Kopits, 1992; Rosenberg, 1992).

In contrast, Romania's industrial production plummeted by 17 percent in 1991 . The decline has continued in 1992 and 1993. Following a 12 percent decline in 1990, Bulgaria's economy declined by a shocking 22 percent in 1991. Recently, payment delays common in Rumania were eased through the liberalization of the foreign exchange market and investment opportunities (Flint, 1994). This is ex- 
plained by the fact that Bulgaria's economy was the most dependent on the former U.S.S.R. and was hit severely by the breakup of the regulated trading requirements of the former U.S.S.R. The economy of Albania, by far the poorest country in Europe, is in economic free-fall (Rosenberg, 1992).

The largest unresolved question appears to be the future of the former Soviet Union, where the enormity of potential markets is matched only by the economic and political confusion generated by the country's dissolution (Ring, 1993). However, the 12 republics are starting their own unique strategies for economic reform/ development. Because they are so different in their culture, religion, history, and ethnic make-up, they will require a special dynamic cluster analysis in the future.

Entrepreneurs will have to deal with a wide variety of issues in segmenting the macro-market in the former U.S.S.R. The traditional analysis of the former Soviet Union would suggest the following clusters: (1) Russia, Ukraine, and Belarus - being Slavic, Christian Orthodox and with common historical, linguistic, cultural and economic relations; (2) Armenia, Georgia, and Azerbaijan - the Caucuses republics clustered together mainly on considerations of their location, size, and richness of mineral resources ("Can," 1992); (3) the republics of Central Asia - Uzbekistan, Tadjikistan, Kirgizia and Turkmenistan - a dangerous mixture of Islamic fundamentalism and autocratic communism. Moldovia will probably continue to integrate with Romania on the basis of their common origin and geographic proximity. A problematic country in this analysis is Kazakhstan, where more than 30 percent of the population is of Russian origin. Kazakhstan can either move toward the first cluster or revert to its Islamic neighbors of the third cluster.

Although the above clustering scheme is convenient, it hides many problematic areas which are now impossible to predict. For instance, what will happen in the future with the multiple "autonomous republics" and "autonomous provinces" (Shevardnadze, 1993)? Many of them are located in the old Russian Federation, some of which, like Dagestan, have claimed independence and sole authority over their national resources. One of the bright spots in the political unrest in Russia between Boris Yeltsin and the Supreme Soviet legislators was bringing Yegar Goider back as First Deputy Prime Minister. It is contemplated by observers that among Goider's programs will be to liberalize foreign trade because there are too many restrictions (Galuszka, Stead \& Miller, 1993). The political climate in Russia appears to be stabilizing and economic progress has been accomplished but not without costs (Thorniley, 1994).

A traditional cluster analysis of Eastern Europe is a static one, based on studying the current characteristics of the separate elements without looking at the dynamics of the region as a whole. A more accurate means of reflecting the context of European integration, where certain rearrangements are likely to take place in the near future, is needed. "Assessment [of the region] is very often made more on the basis of historic political events and coalitions than sound economic analysis, ... very often we take Poland, Hungary and Czechoslovakia together. We can doubt whether that's correct in terms of economics. Quite often we put Bulgaria 
and Romania together. Again, that can be questioned" (Andriessen, 1992, p. 14). Some of the developments worth watching are: (I) the closer integration of the Czech republic to Germany, especially after Czechoslovakia split into two separate countries (Kuchan, 1992); (2) the formation of the Austrian-Hungarian axis which might also attract Italy (if EC divides into two circles of integration) and the former Yugoslav republics of Slovenia, Croatia and what will be left of Bosnia (Kaikati, 1992); (3) the formation of the Baltic trading area consisting of Germany, Poland, the Baltic Republics, some regions of Russia, and the Scandinavian countries; and (4) the development of the turbulent Balkans where Bulgaria is moving quickly forward in its economic and political reforms, while Romania and Serbia are still ruled by their former communists. A major impact, as a whole, could be exercised by the situation in the former Soviet Union where the democratic process has not become irreversible yet and the threat of possible dictatorship still hangs in the air (Kaikati, 1992; Galuszka, Stead \& Miller, 1993; Zlenko, 1993). But one very encouraging sign has appeared in Russia, the emergence of a well educated, energetic under- 40 generation which is quickly adapting to a "free" marketplace and showing energy unheard of in the days of the Soviet command economy (Kranz, 1994).

\section{Dynamic, Entrepreneurial Segmentation}

A more dynamic segmentation process is needed to help insure accurate economic/political/cultural data for the entrepreneurial organization. A static, historic segmentation orientation provides little assurance to the "rifle shot" strategies of most entrepreneurial organizations. Conducting a customized, dynamic segmentation strategy entails four related steps: (1) "average" country analysis; (2) relevant industry characteristic analysis; (3) progressive cross-cultural analysis; and (4) evaluation of governmental "externalities," i.e., exogenous factors/incentives given by each country. Each of these stages of the segmentation strategy will be briefly discussed to highlight the data generated by that phase of the segmentation analysis (see Exhibit One).

\section{"Average" Country Analysis}

To provide the entrepreneurial organization's management with an objective gauge of the market potential in the Eastern European/post U.S.S.R., an "average" country needs to be constructed. A listing of significant demographic variables, such as those given in Exhibit Two, may be used to indicate what the characteristics in the "average" market are in Eastern Europe/former U.S.S.R. This step helps the entrepreneur construct an "artificial" frame-of-reference to be used in assessing market potential relative to the "average" country in these regions. At the same time, this analysis reduces the tendency to compare data to the home country of the entrepreneur. The data for all the countries are summed and then divided by the number of countries, in this case five. This technique can also be used for regions within each country if the data are available. 


\section{Exhibit 1: Dynamic Entrepreneurial Segmentation}

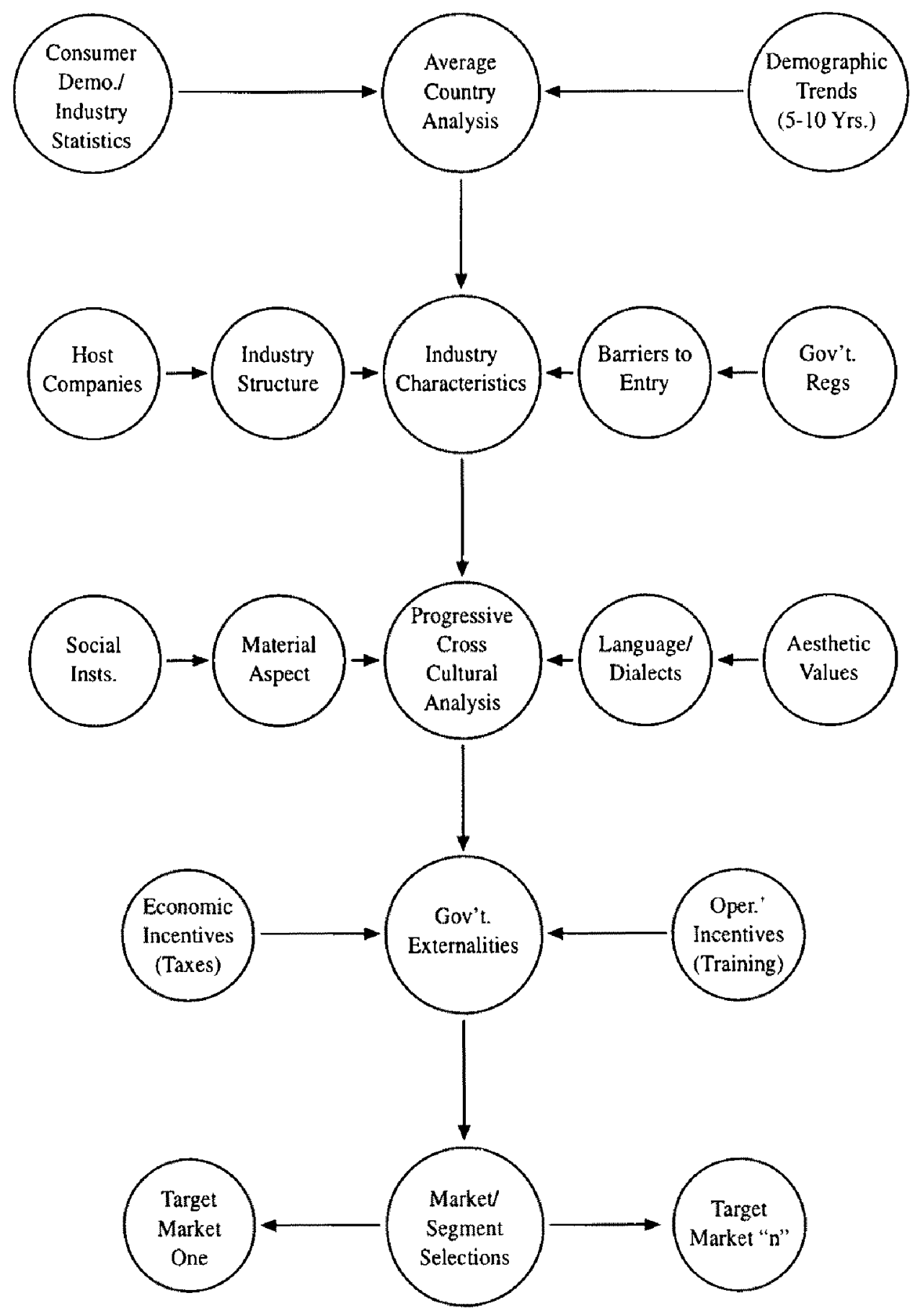




\section{Exhibit 2 \\ Average Country Analysis Variables}

(1) Population

(2) National Income - Per Capita, \# Per Household

(3) Gross Domestic Product

(4) Manufacturing as a Percentage of Gross Domestic Product

(5) Average Hourly Earnings in Manufacturing

(6) Total Exports and Export Market

(7) Total Imports and Import Partners

(8) Import/Exports To and/or From Eastern / Western Countries

(9) Private Consumption Expenditures

(10) Personal Consumption Expenditures

(11) Passenger Autos, Trucks in Use

(12) Telephones, TVs, Radios in Use

(13) Electricity Production

Demographic variables are examined for trends of last $5 / 10$ years and projections.

\section{Relevant Industry Characteristics Analysis}

To help customize the segmentation process, the entrepreneurial organization must select key market indicators/predictors that significantly influence its industry. These variables will be particular to each industry but should include economic factors that are used in the domestic market for planning and forecasting growth of sales in the industry. For example, in the housing industry and related suppliers' industry, growth is influenced by mortgage rates, the rate of inflation, the number of marriages, the demographic age breakdown of the population, and the number of unabsorbed houses (for detailed discussion see Porter, $1980 ; 1985 ; 1990)$. Every industry has a set of variables that comprise signals of the present/future levels of demand. Most trade associations can provide the entrepreneur with relevant indicators of demand that could be used to enhance the segmentation process for their product even for Eastern Europe. 


\section{Progressive Cross-Cultural Analysis}

To better understand the cultural, social, and economic development variations between the United States and the potential host Eastern European market, the entrepreneurial organization must conduct a cross-cultural analysis. The process investigates: (a) the material aspects of the culture - such as the level of technological and economic development in the country; (b) social institutions - the influence of political, educational, and religious institutions in the market; (c) language - official language, business language, and language taboos in the culture; and, (d) the aesthetic values of art, folklore, and music that are present in the country. This type of analysis is conducted on secondary sources of information. The analysis can assist in determining relevant motivation in a culture, characteristic forms of decision-making, "broad" cultural values associated with product categories. In addition, this analysis can be used to ascertain the appropriate marketing institutions, advertising and pricing necessary to reach the entrepreneurial organization's target market in the host country. A great deal of this information can be obtained from the United States Department of Commerce. One such source, Resource Guide to Doing Business in Central and Eastern Europe, provides an array of beneficial data illustrating economic and cultural similarities/differences in conducting business in Eastern Europe/former U.S.S.R. In addition, this source reviews United States government initiatives, strategy tips on how to approach these markets and a reference section on Trade Development Industry Exports and Foreign Commercial Services district officers. This detailed listing includes trade support contacts including current telephone numbers. The similarities/dissimilarities between the cultures of the United States and the selected Eastern European country aid in the development of the "rifle shot" strategy of many entrepreneurs.

\section{Evaluation of Governmental "Externalities"}

To attract foreign investment and encourage privatization (Reforming, 1992) of industry, each sovereign state can compile an array of inducements for Western businesses that will conduct business with/within its country. For example in Slovania, where 2,500 public sector enterprises will be privatized in 1994 (Crisp, 1994). Government incentives may strongly influence the entrepreneurial organization's selection of countries in the Eastern European market, as well as their mode of operation. Frequently, the following benefits may be provided by Eastern European governments:

- Reduction in effective local tax liability

- Permit accelerated depreciation for high risk situations

- Exemption for fees for registration, financial transactions and local purchase of fixed assets

- Reduction of duties/tariffs on imported raw materials, semi-finished products and equipment to improve production efficiency

- Government subsidy to foreign business to encourage development in certain geographic areas (development loans) 
- Government involvement/ownership of plants and/or favorable leases to foreign producers

- Government protection against foreign and local competition

- Offers to train indigenous laborers

- Assurance of safety of corporate property and employees and

- Adequate compensation if property is expropriated by government officials

The key to effectively employing the dynamic segmentation strategy is tapping information sources for that data needed in the analysis. There are three accessible sources of data to the entrepreneur: (1) Federal government data sources; (2) universities; and (3) private data sources. Each of these data sources will be briefly discussed to assist in directing the entrepreneur interested in dynamic market segmentation.

\section{Federal Government Data Sources}

Knowing which agency can assist and what that agency has in the way of data are the keys to accessing government data (see Exhibit Three). The agency most likely to be able to generate the data needed to ascertain market characteristics is the Commerce Department's International Trade Administration (ITA), which is responsible for promoting exports from the United States. There are 47 district offices and 21 branches of ITA throughout the United States. Each office has access to:

- trade and investment opportunities abroad

- foreign markets (requesting) United States products/services

- service to locate and evaluate overseas buyers and sales representatives

- financing aid for exporters

- list and evaluation of international trade exhibitions

- export documentation requirements

- foreign economic statistics

- United States export licensing and foreign national import requirements

- export seminars and references for a listing of services and data available from ITA

Most of the information about economic trends and consumers are gathered on-site by the commercial offices of the foreign embassies. An additional source of data is the country desk officer in ITA's International Economic Policy Unit. Every country in the world has a country desk officer assigned to it. Desk officers keep up-to-date data on economic and commercial conditions in their assigned country. They constantly update trade regulations, tariffs, economic and political developments, market size and trends and, most important, make assessments of market potential by domestic Standard Industrial Classification Codes (SIC). An invaluable service they provide is information on foreign standards and certifications for each product category. 


\section{Exhibit 3}

\section{Export Services of International Trade Association}

Export counseling. Trade specialists are available at ITA district and branch offices for individualized export counseling.

Agent/Distributor Service. A customized search for interested and qualified foreign representatives will identify up to six foreign prospects who have examined the U.S. firm's literature and expressed interest in representing it.

Commercial News USA. A monthly magazine that promotes the products or services of U.S. firms to more than 110,000 overseas agents, distributors, government officials, and purchasers. Exporters may submit a black and white photo and a brief description of their product or service.

Comparison Shopping. A custom-tailored service that provides firms with key marketing and foreign representation information about their specific products. Commerce Department staff conduct on-the-spot interviews to determine nine key marketing facts about the product, such as sales potential in the market, comparable products, distribution channels, going prices, competitive factors, and qualified purchasers.

Foreign Buyer Program. Exporters can meet qualified foreign purchasers for their product or service at trade shows in the United States. The Commerce Department promotes the shows worldwide to attract foreign buyer delegations, manages international business centers, counsels participating firms, and brings together buyers and sellers.

Gold Key Service. A custom-tailored service for U.S. firms planning to visit a country. Offered by many overseas posts, it combines several services, such as market orientation briefings, market research, introductions to potential partners, an interpreter for meetings, and assistance in developing a sound market strategy and an effective follow-up plan.

Trade Opportunities Program. Provides companies with current sales leads from overseas firms seeking to buy or represent their product or service. These leads are available electronically from the Commerce Department and are redistributed by the private sector in printed or electronic form.

World Traders Data Report. Custom reports that evaluate potential trading partners. Includes background information, standing in the local business community, creditworthiness, and overall reliability and suitability.

Overseas Catalog and Video-Catalog Shows. Companies can gain market exposure for their product or service without the cost of traveling overseas by participating in a catalog or video-catalog show sponsored by the Commerce Department. Provided with the firm's product literature or promotional video, an industry will display the material to select foreign audiences in several countries.

Overseas Trade Missions. Officials of U.S. firms can participate in a trade mission which will give them an opportunity to confer with influential foreign business and 
government representatives. Commerce Department staff will identify and arrange a full schedule of appointments in each country.

Overseas Trade Fairs. U.S. exporters may participate in overseas trade fairs which will enable them to meet customers face-to-face and also to assess the competition. The Commerce Department creates a U.S. presence at international trade fairs, making it easier for U.S. firms to exhibit and gain international recognition. The Department selects international trade fairs for special endorsement, called certification. The cooperation with the private show organizers enables U.S. exhibitors to receive special services designed to enhance their market promotion efforts. There is a service charge.

Matchmaker Events. Matchmaker trade delegations offer introductions to new markets through short, inexpensive overseas visits with a limited objective; to match the U.S. firm with a representative or prospective joint-venture/licensee partner who shares a common product or service interest. Firms learn key aspects of doing business in the new country and meet in one-on-one interviews with the people who can help them be successful there.

\section{Public Universities Data Sources}

The keys to unlocking the wealth of information in university libraries is finding a research librarian who can orient the small businessperson or a student and/or a faculty member who is knowledgeable of their library. These individuals can be hired to access data and to provide information to the entrepreneurial firm very inexpensively. The data that are in libraries can provide significant insight into the market demand for the company's product (see Exhibit Four). For example, if the target group of countries was Europe, a library that have been designated a European Community Depository Library will have an inordinate amount of free data in them.

\section{Exhibit 4 \\ Designated Libraries: European Community Collection}

European Economy, Four times a year.

Periodic report presenting EC Commission analyses of economic conditions and policies within the EC. Features and articles have substantial statistical content.

European Economy, Supplement A: Recent Economic Trends. Monthly.

Monthly report presenting recent trends in basic economic indicators for the EC, total and by country, with comparisons for US and Japan. Covers unemployment rate; trade balance; short-and long-term interest rates; value of ECU in national currency and SDRs; and percent change over preceding period in industrial production; CPI, money supply, and effective exchange rate (export aspect).

\section{European Economy, Supplement B: Business and Consumer Survey Results.}

Monthly report on opinions of business executives regarding current and expected performance of manufacturing, construction, and retail trade; and consumer opinions regarding general economic conditions; for EC countries. 
External Trade: Monthly Statistics. Monthly.

Monthly report presenting detailed external trade data for 12 EC countries, by SITC 1- to 2-digit commodity and country, world region; and/or economic grouping. Includes data on total EC trade with rest of world; and trade of individual member countries with $\mathrm{EC}$ and non-EC trading partners.

Eurostatistics: Data for Short-Term Economic Analysis. Monthly.

Monthly compilation of economic indicator indexes for $12 \mathrm{EC}$ countries, with selected data for US and Japan. Indicators include production by industry group, industry expectations for production and orders, retail and foreign trade, prices, wages, financial transactions, and balance of payments.

Bulletin of the European Communities. Monthly.

Report on activities of EC institutions. Includes data on financing operations, draft and final budget appropriations and resources, development assistance projects, food assistance, and emergency aid; and information on economic, foreign, and administrative policy actions, and Court of Justice cases and decisions.

\section{Agricultural Markets: Prices. Quarterly.}

Report on prices of major agricultural commodities in $12 \mathrm{EC}$ countries. Includes market and fixed prices; EC target, intervention, and threshold prices; and trade levies as applicable for each commodity.

\section{Crop Production: Quarterly Statistics. Quarterly.}

Report presenting detailed data on production and supply of approximately 150 agricultural commodities. Includes data on agricultural land use; and area, yield, production, stocks, trade, and consumption of major field crops, vegetables, and fruits (including nuts and other permanent crops).

\section{Animal Production: Quarterly Statistics. Quarterly.}

Report presenting detailed data on production, stocks, and trade of livestock, poultry, and dairy products by commodity for $10 \mathrm{EC}$ member countries. Covers livestock slaughtering and live animal trade; eggs incubated, poultry hatchings, and chick trade; and milk, butter, and other dairy products.

Energy: Monthly Statistics. Monthly.

Report presenting data on production, consumption or inland deliveries, and trade of coal, oil, oil products, natural gas, and electric power.

Energy in Europe: Energy Policies and Trends in the European Community. Three times per year.

Periodic report on topics related to EC energy supply, demand, and policies. A regular feature examines energy market outlook which includes data on trends and short-term forecasts for production, consumption, trade balance, and stock changes, by energy type; hard coal and coke deliveries, by end user sector; deliveries of selected oil products; electric power plant fuel consumption; and nuclear power generating capacity.

Source: “A Directory of Export Services," Business America, May 7, 1990, pp. 14-18. 


\section{Private Data Sources}

There are over 400 private companies that conduct research to be sold to individual businesses. The key is to determine which companies conduct research on products/industries/countries of interest to the entrepreneurial organization. Where are all of these sources indexed for the entrepreneur? There is one source of this data compiled annually, Findex: The Directory of Market Research Reports, Studies and Surveys. It profiles thousands of reports on the demand for products throughout the world in such categories as: industry reports, company reports, reports on companies that publish reports, publisher/distributor directories (how to contact), and a geographic index to pinpoint the area that may be of interest to the entrepreneur. Unfortunately, Findex is seldom found in university libraries. The index may be purchased $(\$ 275)$ and it provides an entrepreneur with a library of private research conducted by firms throughout the world.

These three sources of information will provide the enterprising entrepreneurial organization with ample information on which to base a market assessment for the international market. However, large volumes of information may create difficulty in sorting and organizing the data into actionable information. The data are available; the entrepreneurial organization must invest the time and effort to gain access to these information sources.

\section{Modes of Entry and Operation in the Eastern European Market for Entrepreneurs}

International market entry mode is an institutional arrangement that makes possible the entry of a company's products, technology, human skills management or other resources into a foreign country. Generally, entry modes can be classified into three major categories: (1) Export/Import entry modes; (2) Contractual entry modes (licensing, franchising, turnkey contracts, technical agreements, service contracts and others) and (3) Investment entry modes (joint venture, foreign subsidiary), (Root, 1982). Each of these modes of entry have unique characteristics that can be utilized by the entrepreneur when entering Eastern European/ former U.S.S.R. countries. Matching the relative advantage of an entry mode and the market "attractiveness" is critical due to the limited resources that many entrepreneurial organizations face when expanding into the international marketplace. Exhibit Five depicts the matching of country cluster "attractiveness" and mode of entry that supports an entrepreneurial organization's strategy. It is important to note that the "average" country analysis is based on a common set of economic characteristics (see Exhibit Four) in combination with key industry indicators selected by the entrepreneurial organization.

To illustrate the value of each entry mode the following selections briefly describes pros and cons of each mode. 


\section{Exhibit 5}

Country Clusters and Mode of Entry

Entry Mode

\begin{tabular}{|c|c|c|c|c|c|}
\hline $\begin{array}{l}\text { Eastern } \\
\text { European } \\
\text { Country } \\
\text { Clusters }\end{array}$ & $\begin{array}{l}\text { Export/ } \\
\text { Import }\end{array}$ & $\begin{array}{l}\text { Foreign } \\
\text { Licensing }\end{array}$ & $\begin{array}{c}\text { Joint } \\
\text { Licensing }\end{array}$ & $\begin{array}{c}\text { Joint } \\
\text { Venture }\end{array}$ & $\begin{array}{c}\text { Foreign } \\
\text { Subsidiary }\end{array}$ \\
\hline $\begin{array}{l}\text { *Above } \\
\text { "Average" } \\
\text { Country }\end{array}$ & & & & $\begin{array}{c}\text { Primary } \\
\text { Mode of } \\
\text { Entry (Rapid } \\
\text { Market } \\
\text { Penetration) }\end{array}$ & $\begin{array}{c}\text { Secondary } \\
\text { Mode of } \\
\text { (Preempt } \\
\text { Entry of } \\
\text { Other Foreign } \\
\text { Competition) }\end{array}$ \\
\hline $\begin{array}{l}\text { "Average" } \\
\text { Country }\end{array}$ & & $\begin{array}{c}\text { Primary } \\
\text { Mode of } \\
\text { Building } \\
\text { Brand } \\
\text { Awareness }\end{array}$ & $\begin{array}{l}\text { Secondary } \\
\text { Entry Mode } \\
\text { (Gain } \\
\text { Production } \\
\text { Relative } \\
\text { Advantage }\end{array}$ & & \\
\hline $\begin{array}{c}\text { Below } \\
\text { "Average" } \\
\text { Country }\end{array}$ & $\begin{array}{c}\text { Primary } \\
\text { Entry Mode } \\
\text { (Est. Contact } \\
\text { For Future) }\end{array}$ & $\begin{array}{c}\text { Secondary } \\
\text { Entry Mode } \\
\text { (Contextual } \\
\text { Expansion.. } \\
\text { Limited Risk) }\end{array}$ & & & \\
\hline
\end{tabular}

* Determination of "Average" country based upon country variables e.g., deomgraphic as well as specific industry related issues selected by the organization undertaking the analysis.

\section{Import/Export Mode of Entry}

The first level of involvement in international markets companies must overcome are their anxieties about the organizations ability to compete in foreign markets (Root, 1994). This feeling of uncertainty is excentuated for entrepreneurial organizations contemplating Eastern European markets. The level of organizational insecurity can be off-set to a degree by selecting an entry mode that reduces the risks by limiting the direct level of involvement in Eastern European markets. The entry modes that fulfills the objective of containment of risk are exporting or importing from Eastern European markets.

The entrepreneurial organization can select between direct or indirect exporting and importing. Direct exporting/importing requires the organization to commit to managing the export/importing activities through their own company. Whereas, the indirect exporting/importing shifts the responsibility for entering the Eastern European market to a specialist in the exportimportation business. There 
is a variety of these experts: (1) export management companies (EMCs) - serve as the international marketing specialist for several manufacturers in noncompetitive lines by adapting their services to each client's products, markets and their own resources; (2) agents, brokers and commission houses - represent manufacturers in the international marketplace much as manufacturers representatives do in the United States; and (3) complementary exporters - contract for private labeled products from a variety of manufacturers to be sold in the international marketplace as a unique product line (Root, 1994). Small entrepreneurial companies may find these entry modes appealing when entering "exotic" markets to reduce the risks associated with selling their products (McDermott, 1993).

As is illustrated in Exhibit Five, the exporting/importing entry strategy may be employed when the market does not warrant a full scale commitment to the market cluster. The timing for high potential, low risk may not be right and the export/import entry mechanism allows for an introductive to the marketplace to be strategically positioned for future growth opportunities. This entry mode also permits the entrepreneurial organization the time to further assess the potential of the Eastern European markets. The export/import mode of entry increases the knowledge and experience of the entrepreneurial organization before attempting a more aggressive, involved mode of entry.

\section{Foreign Licensing (FL) Mode of Entry}

The reasoning behind foreign, licensing, primarily used by Western companies is to: (l) transfer existing technology to these countries; (2) sell licensed products to counteract counterfeiters; (3) avoid the high involvement and risk of joint ventures and foreign owned subsidiaries; and (4) rampart the product back in the home country (Root, 1982; Garland, Farmer \& Taylor, 1990).

Important factors, however, make this mode-of-operation less preferred in Eastern Europe. The first one is the lack of management skills which will negatively affect the operation of the licensee (or the franchisee), and ultimately, the reputation and the brand name of the licenser (Judy, 1992).

Another serious problem, is the existence of grey markets where licenser's products are sold by other unlicensed merchants without permission and without paying the appropriate royalties and fees. Sony experienced such negative results in Poland in 1991 despite increased shipments of Sony products to Pewex, the local company licensed to distribute them in Poland, demand exceeded by far the official supply. Private dealers began selling Sony products on the grey market supplied by "parallel" imports independent of Pewex. Sony considered a number of options to deal with the situation but concluded that opening its own subsidiary would be the best solution because this would give the company control over sales and service, enhance its local image, and fit the corporate philosophy of "global localization" (Wood, 1992).

The third problem, especially for the software industry, is the potential for piracy. By one estimate, more than 90 percent of all software used in Eastern Europe has been illegally copied (Hotopf, 1992). Obviously, pure licensing with- 
out strict control will only add to the headache. The situation, however, is improving with most of the countries enforcing laws that defend private intellectual property.

Still, foreign licensing can be used carefully in certain areas, such as retailing and soft drink bottling, e.g., Coca Cola's and PepsiCo's current agreements with a number of local partners. The Austrian food retailer, with Czech and Slovak subsidiaries, has also four franchises in Poland, two in Hungary, and six in Yugoslavia and plans to open a store in St. Petersburg, as well (Haslach, 1992).

One opportunity for joint ventures for small and medium firms in the United States is to obtain technology rights from companies in Eastern European countries. X-Ray Optical Systems, Inc. a small Albany, New York startup in 1990 has obtained rights to a breakthrough technology that allows X-rays to be highly magnified (Kruytbosch, Silverman \& Pechter, 1992). The technology was developed by a small Romanian company and marketed in the United States by XRay Optical Systems, Inc.

\section{Joint Ventures (JV) Mode of Entry}

Joint ventures as a traditional instrument of entering foreign markets, allow more rapid market access than exports and have lower costs than joint investments. In addition, this mode of entry allows western companies access to sources of raw materials at below market prices (Pfohl \& Lagrde, 1993). However, the legal contract which binds firms with different cultural, economic and political backgrounds can be more perilous than foreign license subcontracting or foreign investment where, in each case, one firm maintains managerial and financial control (Stevens, 1990).

The preferred investment has been joint ventures. In spite of the impressive number of such joint ventures, many of the ventures have yet to function. Of the 5,000 or so joint ventures registered in the former Soviet Union in 1991, only 250 were operational at the end of 1992. ("Economic," 1992).

There has been a steady stream of headline-making MNC joint ventures such as FIAT's plans to invest $\$ 2$ billion in Poland and Phillip Morris' agreement to pay almost $\$ 400$ million for ownership in the Czech cigarette maker - Tabak. It is the small service-oriented businesses that dominate the scene. In Hungary, the average joint venture receives $\$ 130,000$ in foreign capital, and fewer than a quarter of such ventures are in manufacturing (Wood, 1992). Even small entrepreneurial organizations like Ben and Jerry's Homemade, Inc. established a joint venture which has grown to four ice cream shops, employing 100 people in Russia (Doeff, 1994).

Other inherent disadvantages of a joint venture could include: (1) lack of full control over the company which is further worsened when one of the partners lacks basic management skills; (2) serious problems in dispute resolution, especially when the local partner has a completely different attitude to managementworkers relations; and (3) possibility of corruption, particularly when the local directors are government employees in a quickly changing environment in which 
old controlling and supervising institutions are destroyed faster than new, market-based ones are being built (Root, 1982).

Joint ventures will probably continue to be preferred in countries averse to foreign private property, e.g., Russia and the former Soviet republics. This is particularly true in industries which will tend to remain under state control for a longer period of time. This trend will also continue where the risk-sharing incentives are high, e.g., extraction, energy, telecommunications, and other specific large-scale infrastructure projects. Such a project is the International Telecommunications Union consortium that is helping to rebuild Eastern Europe's outdated telecommunications infrastructure for over $\$ 94$ billion between 1994-2000 (LaPlante, 1994).

Such a mode is particularly useful for oil and gas extraction in Russia and the republics, where "there is still a tendency to regard foreign investors as nasty capitalist robbers and where many of the oil barons of Siberia have a less positive attitude" (Fraser, 1992a, p. 7). One such joint venture, White Nights, is a three-way partnership between Phibro Energy of Connecticut, Anglo-Swiss of Texas, and Varyegannyeftegas (a Siberian oil association). White Nights drills for new oil in leased fields. So far, the oil goes to the Russian government and the revenues are split (Fraser, 1992b).

\section{Wholly Owned Subsidiaries (WOS) Mode of Entry}

Some entrepreneurial organizations could progress from export lead expansion to establishing international production and assembly facilities in Eastern Europe countries, but this would be a significant organizational step for most entrepreneurs (Stevens, 1990).

While most firms that are directly investing in Eastern Europe are attracted by the size of the domestic markets, companies from certain industries (such as electrical goods and auto manufacturing) consider this region as an extension of Western Europe, and are establishing production facilities there as elements of their core networks with a view to supplying the entire European market. Western companies can play a major role in the economic transformation of Eastern European economies (Feulner, 1994). Such companies strongly prefer full management control over their Eastern plants in order to ensure world standards of quality and proper management. Although benefits to such investments may not materialize in the short-run, possible first-mover advantages and long-term prospects have induced many to invest there.

The Eastern European scene is dominated by serious players with clear longterm investment strategies such as: GM, Ford, VW, Daimler-Benz, Suzuki (automobiles), Samsung, Daewoo, Matsushita, Siemens (electronics), GE and Electrolux (lighting), Ericsson and AT\&T (telecommunications), Nestle and Unilever (food), Procter and Gamble (consumer goods). Such investments lead to modernization of technology, plant equipment and even infrastructure. Improved road transportation feeds into more efficient distribution of food and other retail goods. Western-style supermarkets and convenience stores have already come to Eastern 
Europe. The conglomerate Austrian food retailer, Julius Meinl, formed Czech and Slovak subsidiaries with food stores in Prague and Bratislava and plans for twenty more. BSN, the French food giant which signed deals in Czechoslovakia and Poland to produce its Danon brand yogurt, plans to run its own trucks and warehouses to ensure fresh delivery (Wood, 1992). The German retail chain, Adler, took over Bulgaria's Denitsa and immediately started opcrations in Sofia.

A heightened cultural sensitivity, however, is needed in order to gain a high profile and to not be viewed as "buying up the home country" (Rosenberg, 1992). An example in this respect is the appointment of a local man as the Chairman of Skoda by VW's management. Officially, the German manager is merely a vice chairman although he actually oversees all operations. In addition, local employees are also being schooled to take over the reins from expatriates, benefiting from language training and regular visits to Wolfsburg, VW's headquarters in Germany, for management seminars (Studemann, 1992).

On the other hand, parent companies should be ready for a long adjusting and modernization process in their East European subsidiaries before profits accrue to the company (LaPlante, 1994). A case in point is GE's purchase of the Tungsram lighting company, considered one of Hungary's most prominent companies. Despite cutting staff by 28 percent and increasing volume by 30 percent since taking control in 1989 , the U.S. company says Tungsram still lost $\$ 14$ million in 1991. Further staff cuts and more training outlays are expected (Wood, 1992). On a smaller scale, Coinmach Industries, Company of Roslyn New York is typical of non-MNCs conducting business in Eastern European countries. The self-serve laundromat to serve Hungary's demand for consumer services will take twice as long to be implemented and become profitable than initial estimates (Steinberg, 1991). The government's State Property Agency's inability to determine which properties will become privatized could result in failure of the entire project.

Another stimulus for opening foreign subsidiaries is to improve prospects for other foreign trade and investment and to follow major customers abroad. This is the case with First Ukrainian International Bank, the largest shareholder of which is a $\$ 1$ billion New York international trading group. The new bank aims to facilitate trade among foreign republics and to begin providing a financial infrastructure for foreign investors in the Ukraine. This is specifically targeted for American companies which showed in a recent survey that the chaotic state of the ex-soviet financial system with its lack of convertible currency is a major stumbling block to increased trade and investment (Kruytbosch, 1992). Several foreign banks have set-up subsidiaries in Eastern Europe, including Citibank (the first to set up a subsidiary in Budapest back in 1986); Austria's Creditaustalt and Girozeutral; Italy's San Paolo di Torino and Banca Commerziale Italiana; France's SocietGnrale, Crdit Lyonnais and Crdit Agricole; and Germany's Dresdner and Deutsche Banks. It is estimated by United States banking regulators that there are now about 20 foreign banks with subsidiaries in the region and 80 representative offices. More are expected to open subsidiaries in the next year or two, 
particularly German and Austrian Banks. This is due to the historic links with these countries and the Eastern Bloc, and to a lesser extent, French and Italian Banks ("Can," 1992).

Home government support to large-scale infrastructure projects and other risky investments may turn out to be a serious competitive advantage. At the present time Western firms are coming up against the regions' out-dated telecommunications infrastructure, which many observers cite as the biggest hurdle to achieving success (LaPlante, 1994). As the German, Danish, and Korean examples indicate, joint private and public sector actions, in the form of consortia for instance, are more successful in certain East European countries. This may be due to home country government participation, which seems more dependable to host country decision makers used to dealing, in the past, exclusively with state officials rather than with private companies and individuals.

\section{Summary and Conclusions}

The Eastern European market represents a $\$ 400$ million ultimate consumer market and an industrial sector that is antiquated, depressed and in need of revitalization (Quelch, Joachimsthaler \& Nueno, 1991). Creating a healthy enterprise sector is a key to improving productivity and growth for the Eastern European/ former U.S.S.R. economies over the long term. Close observers of the economic transformation in these countries are almost unanimous in that privatization is the largest and most important systemic issue that these economies face ("Reforming," 1992; Crisp, 1994; Feulner, 1994). This movement must encourage emerging private sector business units (entrepreneurs), as well as promote restructuring and privatization of state-owned assets and enterprises. This type of fluid economic environment is ideal for western entrepreneurs to flourish. Presently, large MNCs and government agencies are leading the way into these unfolding markets, creating "piggyback" opportunities for the astute Western entrepreneur. There are several keys to competing successfully in Eastern European/former U.S.S.R. for entrepreneurial organization:

- Research sources of information that are available in the United States monitoring the very fluid condition of most of the Eastern European/ Russian markets and

- Analyze the basic economic determinants of their business and how these elements are going to be affected in the markets of Eastern Europe and Russia

- Segment the aggregate market into logical country segments and do not assume that there is a homogeneous Eastern Bloc 
- Develop a hypothetical frame-of-references by constructing an "average" country to serve as a point of comparison to each country in Eastern Europe and the former USSR

- Once countries have been arrayed according to their potential market, a progress across-cultural analysis should be conducted to better understand differences among the countries beyond their economic variation

- Examine government incentives being offered to induce western entrepreneurs to do business within each country

- Finally, select a mode of entry to reduce risk of conducting business in the East and at the same time provide the flexibility and latitude to expand their business in the future.

This action plan should provide the necessary steps to help insure success when competing in the Eastern Bloc.

\section{References}

Andriessen, F. Interview. Europe, (1992, March): 14-15.

Bamberger, I. "Developing competitives advantage in small and medium size firms," Long Range Planning 22, No. 5 (1989): 80-89.

Blinderman, M. "One company's success story," Global Trade and Transportation 113, No. 11 (November, 1993): 24.

"Can the banks fly?" The Banker, (September, 1992): 20-44.

Collingwood, H. "Russian industry goes on the block." Business Week, (January 25, 1993): 48.

Collins, S. \& Rodrik, D. Eastern Europe and the Soviet Union in the world economy, Institute for International Economics, Washington D.C., 1991.

Congressional Budget Office, "How the economic transformation in Europe will affect the United States," Congressional Budget Office, Washington D.C., December, 1990.

Crisp, W. "Smooth sailing." Business Eastern Europe 23, No. 29 (July, 1997): 8.

Doeff, G. "Russian revelation." Dairy Foods 95, No. 1 (January, 1994): 24.

Dowling, P. "Hot issues overseas." Personnel Administrator (January, 1989): 66-72. 
Economic Trends. Business Week (December 7, 1992): 24, 104.

Feulner, E.J. "Journey to the East: Investment opportunities in Eastern Europe." Chief Executive 26 (July-August, 1994): 18-20.

Flint, A. "On the mend: Business environment in Romania," Business Eastern Europe 23, No. 29 (July, 1994): 7.

Fraser, H. "Under cover." International Management (February, 1992): 45-47.

Fraser, H. "Save the new Kuwait." International Management, (May, 1992): 79-81.

Galuszka, R., Stead, D. \& Miller, L. "Yeltsin pushes all his chips into the pot." Business Week, (October 4, 1993): 54.

Garland, J., Farmer, R. \& Taylor, M. International dimensions of business policy and strategy, 2nd, Boston: PWS-Kent, Pub. Co., 1990.

"Grabbing new world orders," Business Week, (October, 1992): 110-118.

Haslach, R. "The bright lights of Eastern Europe." Europe (March, 1992): 8-9.

Hotopf, M. "The East hungers for megabites." International Management, (February, 1992): 48-49.

Judy, R. "Prospects for economic and political freedom in Poland." Hudson Country Report, No. 2 (December, 1992): 1-20.

Kaikati, J. "Models of success and failure..." East European Quarterly, XXVI(3), (September, 1992): 291-305.

Khalili, S. "Emigre advantage: You can go home again," International Business 4, No. 7, (August, 1992): 30-35.

Kopits, G. "Fiscal reform in European economics in transition" in Transitions to a Market Economy in Central and Eastern Europe, CCEET, OECD, Paris, 1992.

Kranz, P. "The young the ambitious," Business Week: 21st Century Capitalism, Special Issue, (1994): 128.

Kruytbosch, C. "Capitalism's converts." International Business, (July, 1992): 23-24.

Kruytbosch, C., Silverman, S. \& Pechter, K. "Global go-getters," International Business 5, No. 2 (February, 1992): 14-15.

Kuchan, D. "Altered states." International Management, (August, 1992): 58-65. 
LaPlante, A. "Eastern Europe's virtual curtain." Computerworld, 28, No. 37 (September, 1994): 73-76.

Lo Bello, N. "Why not? Yanks start english-language weekly in Prague," Editor \& Pubఏisher 125, No. 35, (August 29, 1992): 28-29.

Manakkalathil, J.C. \& Chelminski, P. “The central European three: Opportunities and challenges." SAM Advanced Management Journal 58, No. 3 (Summer, 1993): 28-36.

McDermott, K. "Trailblazing in emerging markets: The rewards outweigh the sometime quirky risks of selling to developing nations." D\&B Reports 42, No. 3 (May-June, 1993):16-19.

Miller, W. "Europe 1992: Regionalism and globalism." The International Executive (October, 1991):28-35.

Nakarmi, L. "Can Korea unite and conquer?" Business Week, (November 16, 1992): $52-55$.

Okoroafo, S. "Modes of entering foreign markets." Industrial Marketing Management, 20, (1990): 341-345.

Poe, R. "Gold rush": Your small business can make millions in the U.S.S.R. and the Eastern Bloc," Success 37, No. 7 (September, 1990): 33-42.

Pfohl, H.C. \& Lagrde, R. "Sourcing from Central and Eastern Europe: Conditions and implementation." International Journal of Physical Distribution and Logistics Management 23, No. 8 (October, 1993): 5-16.

Porter, M. Competitive strategy, Free Press: New York, 1980.

. Competitive advantage, Free Press: New York, 1985.

The Competitive advantage of nations, Free Press: New York, 1990.

Puchev, P. "The Bulgarian executive." The International Executive, (October, 1991): 2324.

Quelch, J., Joachimsthaler, E \& Nueno, J. “After the wall: Marketing guidelines for Eastern Europe." Sloan Management Review (Winter, 1991): 42-51.

Quelch, J., Brizzell, R. \& Salama, E. This marketing challenge of Europe 1992, Reading MA: Addision-Wesley Publishing Co, 1991.

Reforming the Economics of Central and Eastern Europe. Organization of Economic CoOperation and Development, Paris, France, 1992. 
Ring, M. "Countertrade business opportunities in Russia." Business America 114, No. 1 (July, 1993): 15-17.

Root, F. "Entry strategies for international markets." Lexington, MA: Lexington Books, 1982.

Root, F. Entry Strategies for International Markets. 2nd Edition, Lexington, MA: Lexington Books, 1994.

Rose, B. "The scramble for oils last frontier." Business Week (January 11, 1993): 4243.

Rosenberg, L. "Economic transition in Eastern Europe..." East European Quarterly, XXVI 3, (September, 1992): 361-277.

Savona, D. "Crude caviar and capitalism." International Business, (February, 1992): 7274.

Shevardnadze, E. "Georgia's security outlook." NATO Review, 41, No. 4(1993): 710.

Simurda, S. "The rush for Russian experts." International Business (August, 1992): 8283.

Sokoloff, S. "Beating the rush to Russia," New England Business 13, No. 2 (February, 1991): $58-59$.

Steinberg, C. "Spin cycle," World Trade 4, No.7, (November, 1991): 40-44.

Stevens, C. "Technoglobalism v technonationalism." Columbia Journal of World Business, (Fall, 1990): 42-49.

Studemann, F. "Baltic renaissance." International Management, (February, 1992): 42-43.

Studemann, F. Skoda. International Management, (March, 1992); 47-49.

Thorniley, D. "Russia: No new is good news." Business Eastern Europe 23, No. 29 (July, 1994): 2.

United Nations World Investment Report 1992...Department of Economics and Social Development, 1992.

Wood, Barry. "The Eastern bloc two years later." Europe (March, 1992): 12-13.

Zlenko, A. "Ukrainian security and the nuclear dilemma." NATA Review 41, No. 4 (1993): 11-15. 